This is the Accepted Manuscript of the article:

Gürkan, Ali and Jorge Díaz Cintas. 2018. "Developing Subtitling for the Deaf and the Hard-of-Hearing in Turkey", in Jorge Díaz Cintas and Kristijan Nicolić (eds) Fast-Forwarding with Audiovisual Translation. Bristol: Multilingual Matters, 173-191.

www.multilingual-matters.com/display.asp?k=9781783099368

\title{
10 Developing Subtitling for the Deaf and the Hard-of-Hearing in Turkey
}

\author{
Ali Gürkan and Jorge Díaz Cintas
}

\section{Introduction}

Information has been a source of power since time immemorial. In warfare, having ample and reliable information about the enemy was an asset that substantially affected the result of the combat and could easily lead to the destruction of a nation. All countries have created intelligence agencies to gather any kind of information that may be of use to their society. However, information is not only required for making major decisions that may affect the present and future of a society, it is also instrumental in making ordinary decisions such as deciding when to go fishing depending on the weather conditions. Information is therefore essential for people from all walks of life.

The importance of controlling information and people's-desire to access, restore and (mis)use it continues to be rife, though the biggest change in the modern world, as discussed by Holvast et al. (2005: 145), is the fact that thanks to information and communication technologies (ICTs) individuals now 'have, for the first time, a convergence of all the technical components with the result that the consequences have been more rapid and radical'. Information is at the heart of many governments' strategies and policies and ICTs have so deeply affected communities and peoples that we are commonly said to be living in an information era and an information society (Castells, 2010; Crawford, 1983). There is a continuous flow of information that people depend on to perform a great variety of activities such as learning a new language, deciding on a tourist destination, buying a product or service or finding a treatment for an illness. Given its centrality, it can be argued that we now live a life of information addiction and it is because of this growing importance and prevalence of information and technology in our society that issues have been raised as to their dissemination and availability, particularly among citizens with sensory disabilities. Technology goes hand in hand with most economic and social developments and has unleashed many opportunities for those who master it, but it also risks bringing about the exclusion of individuals, communities and regions that do not have proper access to ICTs, thus creating a digital divide. According to figures provided by Dutton (2004), $70 \%$ of internet users live in the 24 richest countries, a figure supported by a more recent report published by the International Telecommunications Union (2015), in which it is claimed that only 9.5\% of the 940 million inhabitants in the least developed countries have access to the internet. The benefits and opportunities brought about by technology tend to improve people's lives, but individuals who lack the necessary skills and tools run the risk of being left behind and more isolated than ever before.

People with disabilities are one of the most disadvantaged groups in society when it comes to access to technology and information as this is closely linked to the use of special tools, the provision of certain services and the existence of legislation. The UN has long realised the importance of access to information, declaring accessibility as one of the basic human rights. Indeed, the Convention on the Rights of Persons with Disabilities (Web 1), adopted in 2007, establishes in its Article 1 the aim to 'promote, protect and ensure the full and equal enjoyment of all human rights and fundamental freedoms by all persons with disabilities'. However, without the necessary measures in place, as discussed by Ellcessor (2012), people with sensory 
This is the Accepted Manuscript of the article:

Gürkan, Ali and Jorge Díaz Cintas. 2018. "Developing Subtitling for the Deaf and the Hard-of-Hearing in Turkey", in Jorge Díaz Cintas and Kristijan Nicolić (eds) Fast-Forwarding with Audiovisual Translation. Bristol: Multilingual Matters, 173-191.

www.multilingual-matters.com/display.asp?k=9781783099368

disabilities cannot fully partake in the new mediascape, to which they are only partially invited, and they will continue to find it difficult to integrate and participate unless the right steps are taken to facilitate their access. Given that the technology required to allow full access to audiovisual media is already available, the question remains whether it is financial pressure and/or lack of enthusiasm that lie behind Turkish media providers's reluctance to supply the necessary services to guarantee full accessibility.

Turkey is currently in the process of transforming into an information society, aiming to become a country that 'uses information and technology as an effective tool that produces more value with information-based decision-making processes' (State Planning Organization, 2006: online). In this environment, the role of ICT in the economic and social spheres becomes the catalyst to 'ensure sustainable growth and competitiveness' (State Planning Organization, 2006), with the ultimate goal of benefiting all segments of society by promoting the participation of all citizens in this transformative process. However, the affirmation of this intention does not guarantee in itself that access to information is available to citizens with disabilities; a fact that is corroborated by the results of a statistical report conducted in 2010, which indicates that $60.6 \%$ of the Turkish disabled population do not have access to a computer, a mobile phone or the internet (State Planning Organization, 2011). Against this backdrop, deaf and hard-of-hearing people are two of the most neglected groups when it comes to the availability of appropriate services since accessibility is generally associated with physical rather than sensory disabilities. And yet, even though simple and cost-effective solutions exist, such as subtitling or sign language interpreting (SLI), which facilitate access to audiovisual media for people with hearing impairments, hardly any productions are accessible nowadays on Turkish TV, making a travesty of the government's pledge to promote access to information. Some positive changes have taken place, such as the signing and ratification of the UN Convention on the Rights of Persons with Disabilities or the provision of SLI on some channels, but the fact remains that deaf and hard-of-hearing people are not anywhere near their hearing counterparts when it comes to access to information.

This article analyses the situation of subtitling for the deaf and the hard-of-hearing (SDH) in Turkey, particularly on TV, which is still the main source of information for most people in the country. Firstly, it discusses the profile of people with hearing impairment in Turkey, including their level of education, knowledge of Turkish Sign Language (TSL) and TV viewing habits. Secondly, legislation concerning the rights of people with a hearing disability is presented and analysed, followed by a discussion on the state of SDH on Turkish television.

\section{The Deaf and the Hard-of-Hearing in Turkey}

To best cater for the needs of people with a hearing impairment, it is crucial to know and understand this target audience. Their language preferences, educational background and literacy levels as well as their expectations and preferences when confronted with audiovisual media are all factors that should play a decisive role in deciding the most appropriate approach to accessibility services.

\section{General overview}

Deaf and hard-of-hearing people may share having a hearing impairment, but glossing them over as a homogenous and unified group, as it is often done in the provision of access services, risks overlooking the fact that this sector of the population represents a wide range of individuals with different capabilities and sensory limitations. 
This is the Accepted Manuscript of the article:

Gürkan, Ali and Jorge Díaz Cintas. 2018. "Developing Subtitling for the Deaf and the Hard-of-Hearing in Turkey", in Jorge Díaz Cintas and Kristijan Nicolić (eds) Fast-Forwarding with Audiovisual Translation. Bristol: Multilingual Matters, 173-191.

www.multilingual-matters.com/display.asp?k=9781783099368

For Neves (2005:83), 'deafness may be defined in terms of audiological measurements, focusing on the causes and severity of the impairment, but it can also be seen in terms of social integration and language usage'. According to Action on Hearing Loss, a charity based in the UK, there are four different levels of hearing loss, defined by the quietest sound that people are able to hear and measured in decibels: $25-39 \mathrm{~dB}$ is considered mild, $40-69 \mathrm{~dB}$ moderate, $70-94 \mathrm{~dB}$ severe and over $95 \mathrm{~dB}$ profound. Depending on their degree of loss, people have different capabilities and difficulties, which will in turn have an impact on their preferred way of communication. People with mild hearing loss may communicate easily by using a spoken language whilst people with severe or profound hearing loss may prefer to communicate in sign language (SL). Linguistically speaking, a person born deaf is considered 'pre-lingual', while they are 'post-lingual' if deafness has occurred after having acquired a spoken language. From a sociocultural perspective, being 'deaf' refers to the physical condition of being unable to hear; yet, being 'Deaf' is a conscious decision to belong to a specific cultural group, whose means of communication tends to be an SL. These categorisations explicitly point not only to the difficulty but also to the importance of providing the appropriate access services to the right segment of the audience. Although, at present, it does not seem to be financially viable to provide different subtitles for each of these groups, it is important to bear these differences in mind when preparing subtitles.

There are two sets of official statistics provided by the Türkiye Istatistik Kurumu TTurkish Statistical Institute, TÜIK] on the number of people with disabilities in the country: one is from 2002 and the other is from 2011, which is actually a population and housing census containing limited information on the profile of people with disabilities. According to the statistics from 2002 (Web 2), of a total population of circa 67 million in Turkey, around 1.75 million (2.61\%) had a disability and some 250,000 individuals $(0.37 \%)$ were hearing impaired. By 2011, with an increased population of 75 million, the percentage of individuals with a disability or hearing impairment had risen to $6.9 \%$ (5.1 million) and 4.8\% (3.6 million), respectively. In the latter group, $1.1 \%$ could not hear or had difficulty hearing even if using hearing aids and 3.7\% had declared some difficulty in hearing (TÜIK, 2011: 80). These figures, if slightly higher, are in line with those provided by the World Health Organisation (2013: 2), which, for the same year, estimates the disabling hearing loss prevalence per 100 population to hover between $2.72 \%$ and $4.41 \%$, that is, between 2.04 and 3.3 million Turkish people. The wide discrepancies between the 2002 and 2011 reports are striking, though, which together with the dearth of national statistical research on the topic bring to the fore the difficulty of providing reliable data on the actual number of people with (hearing) disabilities in Turkey. One of the problems at the root is the lack of consistency when defining people with hearing impairments and, for instance, in the 2011 census individuals who stated that they could hear with the help of a hearing aid or who were under the age of three were, rather surprisingly, not considered as having a hearing impairment (TÜIK, 2011: 80). This issue of nominal inconsistency is also raised by Kemaloğlu (2010), who highlights the fact that the 2002 research did not define 'hearing loss' and the figures provided depended entirely on the declaration of the people who took part in the survey,

The unreliability of the figures makes it difficult to determine the exact number of people with hearing disabilities and virtually impossible to classify them according to the severity of the impairment or their linguistic competence. Some glimpses can be obtained from dispersed sources. For instance, the percentage of people with a hearing disability of greater than $40 \%$ was estimated at $83.4 \%(13,779$ people) in another set of official statistics produced by TÜIK (2010) on the problems and expectations of disabled people, though the segment of population covered was very small: 280,014 disabled people who were registered in the National Disabled People Database at the time. The figures from the 2002 and 2010 reports provide limited data on the onset of the hearing disability. The former indicate that $29.49 \%$ of people with hearing disabilities have a congenital disability, without providing any specific details on the age; whereas the set of statistics from 2010 volunteers more details about the onset of the impairment and claims that $62.8 \%$ of hearing impaired people have developed a hearing disability before reaching the age of one (TÜIK, 2010). Although these records might help us conjecture a potential number of users of SL in Turkey, it is virtually impossible to know the exact amount. Nonetheless, Kemaloğlu (2010) estimates the number of D/deaf people to be between 85,000 and 
This is the Accepted Manuscript of the article:

Gürkan, Ali and Jorge Díaz Cintas. 2018. "Developing Subtitling for the Deaf and the Hard-of-Hearing in Turkey", in Jorge Díaz Cintas and Kristijan Nicolić (eds) Fast-Forwarding with Audiovisual Translation. Bristol: Multilingual Matters, 173-191.

www.multilingual-matters.com/display.asp?k=9781783099368

100,000 , of whom about 40,000 are at the age of active participation in education and the work force. This, of course, does not take into consideration hard-of-hearing people, whose numbers are increasing as the population gets older.

Based on linguistic criteria, Kemaloğlu (2010: 1) distinguishes between işitsel yetersizlikten etkilenmiş birey (IYE) [a person who is affected by hearing loss] and farkl iletişim yöntemleri geliştiren işitsel yetersizlikten etkilenmiş birey (FITYE) [a person who is affected by hearing loss and develops different means of communication]; the latter being a term to refer to people who are $\mathrm{D} /$ deaf and part of a community who has its own and distinct way of communicating. In this chapter, 'deaf and hard-ofhearing' and 'Deaf' will be used, instead of IYE and FITYE, to refer to these two different groups of people. Kemaloğlu (2010) claims that an early diagnosis, the use of hearing aids and the participation in a rehabilitation process are instrumental in the development of a spoken language among deaf and hard-of-hearing people, whereas for others who do not have the same opportunities, their chances to develop a spoken language are minimal. The hearing cortex in the brain of people with severe or profound deafness loses its potential to develop after two years of age, when this cellular structure is transformed into a partially visual and partially somatosensory cortex (Kemaloglu, 2010). As the speaking ability is closely dependent on the hearing ability, people with severe hearing impairment from an early age are less likely to develop their speaking ability without appropriate measures. To compensate, deaf people tend to develop other sensorial abilities such as visual and three-dimensional perceptions. Deaf children, thus, try to understand their surroundings through these other sensorial abilities though it is usually not enough for full comprehension and they tend to suffer from learning difficulties and from a lack of conceptual knowledge, unless they are guided through a special education programme.

As far as Turkey is concerned in terms of early diagnosis, the National Newborn Hearing Screening programme was first conducted in 2003 but it was not implemented in all provinces, let alone in small towns. According to Bolat et al. (2009), 764,352 children were screened between 2004 and 2008, which constituted $13 \%$ of all children born during that period. In addition, research conducted by the audiology departments of Hacettepe and Gazi universities shows that the age of diagnosis is 1.6 and the age when children are provided a hearing aid is 2.5 , which might be too late for them to develop a spoken language. Although some improvements have been noted in recent years, it would not be wrong to claim that the majority of the deaf adult people in Turkey did not receive an early diagnose and were not given hearing aids or the opportunity to attend special schools that would have allowed them to develop a spoken language. This fact has to be taken into consideration when providing a SDH service that meets their needs.

\section{Education}

SL was used and taught in the Ottoman palace to communicate with the hearing impaired and mute people who served the royal family (Miles, 2009). According to Gündüz (2014), the first institution to provide special education in Turkey, during the Ottoman state, was a school for the hearing impaired founded in Istanbul by Grati Efendi around 1889, during the reign of Sultan Abdülhamid II (18761909). The first deaf teacher of this school was Pekmezyan, a graduate of a Parisian deaf school. There was a major schooling movement during this period and four more schools for the deaf were also founded during the crown years of Abdülhamid II in Merzifon, Corfu, Selanik-Thessalonica and İzmir (Turgut and Taşc1 2011). SL was used in both İstanbul and İzmir deaf schools despite the resolution of the international Milan Conference in 1880 forcing oralism to be adopted as the only or best approach for the education of the hearing impaired; a decision that would affect the education of deaf children for the next hundred years (Mliczak, 2015). As for the other schools, there is not solid information about the education system they followed (Kemaloğlu \& Kemaloğlu, 2012).

The sign method was initially adopted in the education of Turkish deaf people in the 1880s, and it was not until 1925, after the foundation of the Turkish Republic and during the period of Westernisation, that the method of phonetically learning Turkish with the help of gestures 
This is the Accepted Manuscript of the article:

Gürkan, Ali and Jorge Díaz Cintas. 2018. "Developing Subtitling for the Deaf and the Hard-of-Hearing in Turkey", in Jorge Díaz Cintas and Kristijan Nicolić (eds) Fast-Forwarding with Audiovisual Translation. Bristol: Multilingual Matters, 173-191.

www.multilingual-matters.com/display.asp?k=9781783099368

started to be implemented by the headteacher of the İzmir deaf school (Kemaloğlu \& Kemaloğlu, 2012). He was determined to teach speaking to deaf and mute pupils and believed that the sign method hindered the development of a spoken language. During the same period, three more deaf primary schools were opened with the oralist approach in Ankara, İstanbul and Diyarbakır (Gök, 1958), later transferring from the Ministry of Health and Social Services to the Ministry of Education in 1951 (Girgin, 2006), thus marking the beginning of formal special education in Turkey. Although the move was seen as a positive step towards the provision of unified and systematic special education for disabled people, it also led to the supremacy of the oralist approach and the disappearance and prohibition of SL in educational settings. Kemaloğlu and Kemaloğlu (2012: 72) report the experience of an elderly deaf informant, who claims that "teachers and special teachers were like the "enemy" to the SL because it was thought that the SL was preventing speaking'. Seventy years after the Milan Conference, the use of SL in the education of hearing impaired people was also ruled out in Turkey.

The prohibition on the use of SL was a turning point in the education of deafpeople. Its effects can be felt even today as the oralist approach is still prevalent in educational settings in Turkey despite the fact that most Western countries acknowledge the importance and positive effects of SL in the classroom. Adopting only the oralist approach is unlikely to be a successful pedagogical strategy for the development of a spoken language, which is closely related to the hearing ability of an individual. As previously mentioned, hearing impaired people who have not received a hearing aid or followed proper treatment before the age of two are highly likely to lose their chance to develop a spoken language and tend to communicate in SL. Considering that the National Newborn Hearing Screening programme was only launched in 2003 and that the average age of children who get a hearing aid is 2.5 , the severity of the situation can be better understood. Firstly, the oralist approach risks excluding older individuals who are at a too-late stage to develop a spoken language and, secondly, the late age at which children are being provided with hearing aids reduces their chances to become successful oral language users. Forcing a specific education method that does not seem to suit many hearing impaired people can have the detrimental effect of deteriorating these individuals' communication skills and personal development. Indeed, it risks excluding them from society rather than helping them to develop the communication and interpersonal skills that will help them to integrate and participate in society. Although using SL is nowadays considered a basic human right and a sine qua non for education and public services, an aural/oral approach is still being forced in the education of some hearing impaired people in Turkey.

Despite the unreliability of the figures available on the education levels of disabled people in Turkey, the common feature they all share is the wide gap that exists between disabled people and the general public. According to the survey carried out by TÜIK in 2002, the percentage of illiterate disabled people is $36 \%$ while it drops to $13 \%$ for the rest of the population. In the Survey on Problems and Expectations of Disabled People (TÜIK, 2010), the illiteracy rate for disabled people goes up to $41.6 \%$ and the one for people with a hearing loss stays at $31.6 \%$. The same study finds that only $11.1 \%$ of people with a hearing loss are at high school level or above. The Population and Housing Census (TÜIK, 2011) is more positive in its outlook and estimates the percentage of illiterate disabled people to be $23.3 \%$, in contrast to $4.5 \%$ for the general public, while only $2.6 \%$ of disabled people attend higher education. As for people who have great difficulty in hearing or cannot hear at all, the illiteracy rate increases to $29.1 \%$ with $19.7 \%$ not completing their primary education. These statistics highlight the urgent need to do more in order to improve the education of people with disabilities and, in this respect, SDH has the potential to improve literacy as it has proved to be crucial and 
This is the Accepted Manuscript of the article:

Gürkan, Ali and Jorge Díaz Cintas. 2018. "Developing Subtitling for the Deaf and the Hard-of-Hearing in Turkey", in Jorge Díaz Cintas and Kristijan Nicolić (eds) Fast-Forwarding with Audiovisual Translation. Bristol: Multilingual Matters, 173-191.

www.multilingual-matters.com/display.asp?k=9781783099368

instrumental in the development of viewers' reading abilities (Caimi, 2013; Kothari \& Tathagata, 2007; Kothari et al., 2004; Linebarger et al., 2010; Stewart \& Pertusa, 2004; Yüksel \& Tanrıverdi, 2009; Zárate 2014). Nonetheless, the sociocultural reality of the hearing impaired population has to be duly taken into account when producing SDH since subtitles prepared at a reading speed above the capabilities of the target audience risk becoming a source of frustration rather than a tool for education and enjoyment.

\section{Turkish Sign Language}

The oldest usage of SL was recorded in Anatolia, where it was used by the Hittites (1200-2000 BC) to participate and work in religious ceremonies (Soysal, 2001). This supportive environment towards hearing impaired people was sustained during the Ottoman Empire $\left(14^{\text {th }}\right.$ $19^{\text {th }}$ centuries). Although there is little information about the lives and education of hearing impaired people outside the palaces, it is a known fact that they were appointed as special servants to the royal family and to the sultans themselves, exerting various responsibilities from executing or providing intelligence to entertaining the sultan or serving the royal family. Being deaf and knowing SL was a valuable asset to be employed in the Ottoman courts. Miles (2009) states that there is evidence of the development of a complex communication system, the Ottoman sign language (OSL), which was capable of conveying even difficult matters in a detailed manner. This language was formally taught in the Topkapı palace by experienced deaf users, including those who had retired from service in the palace (Miles, 2009), and was also learned by some courtiers and even sultans for its practical benefits, thus contributing to the perpetuation of OSL for around 500 years.

Although OSL was used, taught and transmitted to the subsequent generations, there is no firm evidence on whether it constitutes the origin of the TSL, tough, as argued by Miles (2009), it seems legitimate to expect OSL to have contributed, to some extent, to the development of TSL. As previously mentioned, the first deaf school in the Ottoman Empire was founded in İstanbul around 1889 to teach hearing impaired people with SL, whose alphabet, as argued by Kemaloğlu and Kemaloğlu (2012: 71), was one-handed and 'most probably originated from French SL and used by adding some extra finger positions to demonstrate Arabic letters and Turkish vowels of the Ottoman Turkish'. This language continued to be used until the alphabet revolution of 1928, which changed the Turkish alphabet from Arabic to Latin. After this episode, a two-handed manual alphabet similar to modern TSL started to be used. It was around this period that the idea of deaf people being educated with an oralist approach began gaining ground, leading some 20 years later to the banning of TSL in schools and the adoption of the oral method as the dominant one in the education of deaf people. This lack of interest in TSL hindered all research on the topic as well as the development of a national, unified SL system (Akalin, 2013), giving rise to a multitude of systems that differ from region to region, making it difficult for hearing impaired people to communicate among themselves. For a long time, the only manual available was the Guidebook of Turkish Sign Language for the Adults, published by the Ministry of Education in 1995 and, as explicitly mentioned in the title, intended for deaf adults only as children were supposed to develop their speaking ability in the oralist primary schools.

The importance of SL in the classroom and as a rightful means of communication for hearing impaired people has begun to be realised in the last decade. Article 15 of the Turkish Disability Act No. 5378, which came into force in July 2005, considers TSL as a rightful tool for the communication and education needs of people with hearing disabilities and gives the Turkish 
This is the Accepted Manuscript of the article:

Gürkan, Ali and Jorge Díaz Cintas. 2018. "Developing Subtitling for the Deaf and the Hard-of-Hearing in Turkey", in Jorge Díaz Cintas and Kristijan Nicolić (eds) Fast-Forwarding with Audiovisual Translation. Bristol: Multilingual Matters, 173-191.

www.multilingual-matters.com/display.asp?k=9781783099368

Language Institution (TLI) the responsibility of creating a national and standard SL system. The standard alphabet of the current TSL was determined two years after the Disability Act in the first ever TSL Workshop that took place on 7 July 2007; a date which since then has been celebrated as the Turkish Sign Language Day. A second workshop, entitled Türk Işsaret Dili Sistemi Hazırlık Çalıştayı [The Preparation of the Turkish Sign Language System], was held in October 2010 with the aim of preparing a dictionary, a grammar book and education materials for TSL, though the results are clearly lagging behind and only the TSL dictionary has been available on the TLI website since 2012, while the remaining objectives seem to have been completely neglected. Some universities, including Boğaziçi, Hacettepe, and Koç, are conducting research on TSL and have compiled dictionaries that they host on their official websites. More recently, thanks to a piece of legislation by the Council of Higher Education, TSL has become an elective course in related undergraduate programmes, although it is not widely available yet and some teachers at deaf schools, who graduated before the passing of this regulation, do not know TSL and use signed Turkish, which is a signed version of spoken Turkish (Kemaloğlu, 2014). Signed Turkish is not an actual language and it simply changes the spoken words with signatures while still using the grammar structure of the spoken Turkish. Although it may seem logical to use signed Turkish to communicate with hearing impaired people, TSL has a completely different grammar structure than spoken Turkish and therefore it is not used or even understood by some Deaf people. This emphasises the need for special education teachers graduating from related programmes to learn TSL so that they can properly communicate with their students.

\section{TV viewing habits of people with disabilities}

Watching TV is one of the two main sources of information for Turkish citizens, the other one being the internet (Karahasan, 2012: 12). Although the latter is gaining popularity exponentially and is used by $46 \%$ of the population, TV is still the most common way of mass communication with $84 \%$ of the population watching it every day (Aykan, 2012: 2). According to statistics from Radyo ve Televizyon Üst Kurulu (Radio and Television Supreme Council; RTÜK, 2013), the national regulatory and monitoring office for radio and television broadcast, people watch TV for 3.5-5 hours a day on average. When it comes to people with disabilities, statistics from an older survey on the television watching/listening trends of the disabled people (RTÜK, 2007) claim that they watch TV for 4.3 hours a day on average and $13.5 \%$ spend 10 hours or more a day in front of the small screen. Compared to other disability groups, the hearing impaired watch TV most on average: 4.5 hours on weekdays and 4.9 hours at the weekends (RTÜK, 2007), foregrounding the significant place that TV occupies in their lives.

The importance of TV for people with disabilities is indirectly supported by the findings exposed in the report of the Symposium on Fighting against Disability Discrimination (Web 3 ), which took place in Ankara in 2010, and concludes that $77.3 \%$ of disabled people have experienced difficulties gaining access to public places, $72.1 \%$ cannot use public transport because of the lack of appropriate provision and $82.2 \%$ have faced some kind of discrimination when trying to partake in free time and leisure activities. These statistics show why accessible TV can be so important for people with disabilities since, for many of them, it is the only and simplest way of connecting with the rest of the world until a fully accessible society in terms of transportation, access to buildings and participation in social activities becomes a reality in Turkey. 
This is the Accepted Manuscript of the article:

Gürkan, Ali and Jorge Díaz Cintas. 2018. "Developing Subtitling for the Deaf and the Hard-of-Hearing in Turkey", in Jorge Díaz Cintas and Kristijan Nicolić (eds) Fast-Forwarding with Audiovisual Translation. Bristol: Multilingual Matters, 173-191.

www.multilingual-matters.com/display.asp?k=9781783099368

As previously discussed, being able to access information is crucial in today's information society, and although this can be achieved in many ways, the role played by TV in a country like Turkey cannot be underestimated. According to the same report (Web 3), $73.1 \%$ of disabled people declare having experienced some kind of discrimination when trying to access information; a percentage that could be substantially reduced by making TV broadcasts more accessible to audiences with sensory impairments. In an attempt to elucidate the opinion of disabled people about the content and the characters portrayed in programmes specifically targeted to them, RTÜK (2007) found that most disabled viewers considered such productions largely irrelevant for helping them solve their problems or provide them with the right guidance, and some even felt that TV channels were exploiting their plight in order to increase their own ratings (RTÜK, 2007). Broadcast time was also an issue as most of the interesting programmes tend to be aired late at night, outside prime time, despite evidence from research indicating that $62.3 \%$ of disabled viewers watch TV between the hours of 18:00 and 21:00 on weekdays (RTÜK, 2007). Although the ultimate goal should be to make all TV programmes fully accessible for people with sensory disabilities, it is vital that in the initial developments their preferences and needs are fully considered, in terms of suitable content to be made accessible as well as time of broadcast.

\section{Legislation}

The design of new technologies that do not take due consideration of the special needs of people with disabilities may complicate their integration into society rather than serving as catalysts for solving some of their problems. For Ellcessor (2012:330), this becomes a vicious cycle in which new technologies and services are developed without considering any accessibility concerns, they are then met with negative critiques and have to be substantially overhauled and revamped if not dismissed altogether. She contends that this cycle is symptomatic of a pervasive apathy on the part of the main stakeholders and claims that technological developments in themselves are not enough to foster and forward accessibility. For scholars like Story et al. (1998: online), this cycle can be reversed through 'universal design', i.e. 'the design of the products and environments to be usable to the greatest extent possible by people of all ages and abilities'. Designing products from inception that are accessible to the widest range of people might also prevent the unnecessary waste of time and resources of having to readapt and readjust obsolete ones. But, in Ellcessor's (2012: 336) opinion, this fight against discrimination on the basis of disability is far from being a seamless process and for any new measures or technological advances to be successful they need to 'have the force of the law behind them in order to ensure their existence, quality and availability'. Encompassing and detailed legislation has to be in place in order to regulate the provision of access services as, given the financial implications, this is unlikely to be championed by product developers or service providers.

Article 10 of the Turkish constitution states that all Turkish citizens are equal before the law regardless of their language, colour, political opinion, religion, race, sex, or philosophical belief, implicitly recognising that measures should be taken to meet citizens' needs and enable them to participate fully in all spheres of life. Acts of discrimination on the basis of any of the above criteria are prohibited and penalised by Article 122 of the Turkish Penal Code, and although neither of these two articles are specifically designed for the sole benefit of people with disabilities, they can certainly be used to campaign for their equal access to rights and greater participation in society. 
This is the Accepted Manuscript of the article:

Gürkan, Ali and Jorge Díaz Cintas. 2018. "Developing Subtitling for the Deaf and the Hard-of-Hearing in Turkey", in Jorge Díaz Cintas and Kristijan Nicolić (eds) Fast-Forwarding with Audiovisual Translation. Bristol: Multilingual Matters, 173-191.

www.multilingual-matters.com/display.asp?k=9781783099368

Since the 1990s, there has been a concerted effort to shift the approach to disabilities from a medical model, which considers disabilities as a form of illness and disorder and burdens only the disabled individual with the vicissitudes of having been diagnosed as such, to a more social model wherein individuals with disabilities are treated on equal terms with all other citizens and the responsibility falls on society to make the necessary adjustments to ensure the complete and equal enjoyment of the rights of disabled people. Although some attempts have been made in the country to pass legislation with a social agenda, they have not been systematic and are rather difficult to account for since they are scattered throughout various acts. The Turkish Disability Act of July 2005 No. 5378, without a doubt the most notable piece of legislation in the right direction, sets its general principles 'on the basis of the inviolability of human dignity and integrity' and charges the State with the development of 'social policies against the exploitation of disability and persons with disabilities. Discrimination shall not be made against persons with disabilities; non-discrimination is the fundamental principle of policies concerning persons with disabilities' (www.ohchr.org/Documents/Issues/Disability/ FirstDebate/Turkey.pdf). The Act also ensures the participation of disabled people, their families and relevant voluntary organisations in all decision-making processes concerning their rights, and introduces some amendments to existing laws to make them compatible with the new legislation.

In the international arena, Turkey signed the UN Convention on the Rights of Persons with Disabilities in 2007 and ratified it nationally two years later, on 27 May 2009. In this sense, and according to article 90 of the Turkish constitution, any international treaties that are duly ratified nationally bear the force of law and become part of national legislation in Turkey. What is more, it also ensures that international agreements shall prevail in the case of potential contradictions with national laws. Hence, it seems legitimate to expect that the Turkish government should take a more proactive stance and encourage appropriate measures to guarantee and enhance the provision of access services to people with sensory impairments. Positive discrimination in the form of adopting extra measures for people with disabilities and special needs is regulated by an amendment to article 10 of the Turkish constitution approved in 2010, which states that 'measures taken for the children, the elderly and the disabled, as well as orphans and widows of the marty $r$ and the veteran cannot be considered to be contrary to the principle of equality' (ILNET, n.d: online). However, as discussed on the Independent Living Network (ILNET, N.D.) project's website there is still a long way for Turkey to secure the ultimate aim of full inclusion:

a simple search through the Regular EU Progress Reports reveals that Turkey is lagging behind in the EU acquis related to disability policies. Some of the remaining issues are: absence of definition in the Turkish legislation of direct and indirect discrimination; the acquis covering discrimination on grounds of inter alia, disability has not been transposed into national legislation; access to education, health, social and public services, the right to vote and to be elected, still remain critical issues for the disabled people of Turkey. All these are also a barrier to enjoyment of the right to independent living. (ILNET, n.d.)

Accessibility in Turkey is generally associated with the provision of access in physical environments and transportation, while access to information and means of communication is not given much prominence despite the crucial role of ICTs in people's lives. Such a situation has prompted authors like Çağlar (2012: 579) to advocate that the right to accessing 
This is the Accepted Manuscript of the article:

Gürkan, Ali and Jorge Díaz Cintas. 2018. "Developing Subtitling for the Deaf and the Hard-of-Hearing in Turkey", in Jorge Díaz Cintas and Kristijan Nicolić (eds) Fast-Forwarding with Audiovisual Translation. Bristol: Multilingual Matters, 173-191.

www.multilingual-matters.com/display.asp?k=9781783099368

information and communication should be a basic human right, entrenched in the constitution or the Disability Act.

When it comes to the broadcasting industry, legislation regulating TV accessibility was finally passed in April 2014, in the form of an amendment to the RTÜK's Directive on Procedures and Principles regarding Broadcast Services (Web 4). This amendment requests the public service provider, Türkiye Radyo Televizyon Kurumu [Turkish Radio and Television Corporation] (TRT), to start providing SDH on news programmes, movies and series, progressively reaching $30 \%$ of the programmes in three years and $50 \%$ in five years. The targeted percentages are slightly lower for private service providers with a national terrestrial broadcast license, i.e. $20 \%$ in three years and $40 \%$ in five years. Although it is not clearly indicated, all the intended programmes to be provided with SDH are of a preprepared nature and there are no current regulations on the provision of live programmes. This amendment also stipulates that public and private broadcast service providers have the obligation of annually declaring statistical data on the levels of accessibility services they provided in the previous year and must send this information electronically to <izlemeburo@rtuk.org.tr> in the first three months of the following year. This regulation may well signal a turning point in the pursuit of fully accessible television for people with disabilities, although for the time being only SDH is considered and other forms of access services, such as SLI and audio description for the blind and the partially sighted (AD), are so far being ignored. The amendment does not specify whether any sanctions will be imposed on stations that do not meet their obligations, which is bound to have a negative effect on the provision of these services as some reluctant broadcasters may find it hard to motivate themselves to reach the prescribed levels of accessibility without the pressure of punitive legislation.

\section{State of SDH in Turkey}

As can be gleaned from the above discussion, accessibility, in general, and in the audiovisual media, in particular, is a neglected issue in Turkey, with barely any programmes being fully accessible on Turkish TV. Traditionally, SLI has been the only access service provided by broadcasters like the public TRT and the private FOX TV, usually for the news. TRT only signs the programme Issitme Engelliler Bülteni [The Bulletin of the Hearing-Impaired], which is broadcast at 17.30 on weekdays on its channel TRT News, while FOX TV provides SLI on its morning news programme, İsmail Küçükkaya ile Çalar Saat [Alarm Clock with İsmail Küçükkaya], broadcast at 07:30 on weekdays. In addition to the news, the live talk show Dada Dandinista, aired by the private broadcaster Star TV every Saturday at 23:30, also counts with an SL interpreter. Of course, these very few programmes are only accessible to those who are fluent in TSL and not necessarily to the whole hearing impaired audience. The other downside of this state of affairs is that their broadcasting time might not be convenient for most deaf and hard-of-hearing people.

The main audiovisual translation mode used on public and private service broadcasting in Turkey is dubbing, which means that domestic as well as most foreign productions are beyond the reach of people with hearing impairments. Some private channels, especially TLC and Bloomberg, broadcast foreign productions such as series and films with Turkish subtitles; however, these interlingual subtitles are not genuinely intended for hearing impaired people and therefore lack many of the important features that are specific to SDH and help people with a hearing impairment to fully enjoy the programmes: indication of who is speaking, description of sounds, and the like. 
This is the Accepted Manuscript of the article:

Gürkan, Ali and Jorge Díaz Cintas. 2018. "Developing Subtitling for the Deaf and the Hard-of-Hearing in Turkey", in Jorge Díaz Cintas and Kristijan Nicolić (eds) Fast-Forwarding with Audiovisual Translation. Bristol: Multilingual Matters, 173-191.

www.multilingual-matters.com/display.asp?k=9781783099368

To date, and despite the amendment of April 2014 mentioned in the section 'Legislation', no SDH is provided on any of the many free-of-charge TV stations operating around the country. However, thanks to increased social awareness, recent positive developments have taken place regarding the provision of SDH in Turkish, both in the pay-per-view sector and on a very few free-of-charge channel websites. Various private service providers such as Channel D (since 2011), Show TV (since 2016) and Star TV (since 2013), together with the public service provider TRT (since 2013) have been broadcasting some of their programmes with SDH, AD and SL for some years now, free of charge, although only on the internet.

TRT, for instance, streams 33 of its programmes on its website (http://engelsiztrt.tv) through its many different channels - TRT 1, TRT Çocuk [Child], TRT Belgesel [Documentary], etc. - with SDH, SLI and AD, while on Star TV and Show TV two and three of their series, respectively, are fully accessible and, on Channel D (http://engelsiz.kanald.com.tr), 55 of its productions are also accessible to people with sensory disabilities, and the number is growing. Foreign productions are not part of the offer and the main genres covered tend to be national series, cartoons, talk shows and quiz shows that viewers can access at any time of the day. Another recent development has been led by Tivibu, a new private TV platform which only broadcasts via broadband internet connection (IPTV). To date, Tivibu has an archive of 21 fully accessible films (with SDH, SLI and AD), only available over the internet, which can be watched on a TV set or any other screen whenever viewers want, and since September 2013, the paid-for satellite television provider Digiturk has been broadcasting various national and foreign films and TV series with SDH, SLI and AD on its movie and series channels. Apart from these developments, the fansubbing website Divxplanet provides SDH for Turkish and foreign movies as well as TV series. Issitme Engelliler ve Aileleri Derneği [Association of the Hearing-Impaired and Their Families], in collaboration with Divxplanet, have developed an archive named Türkçe Altyazılı Türk Filmleri Kütüphanesi (Library of Turkish-Subtitled Turkish Films, www.ied.org.tr/turkcealtyazi.htm), made up of 44 DVDs of Turkish movies with SDH for the enjoyment of the hearing impaired audience, who can either borrow these DVDs or watch them in a place provided by the association. Despite these promising, though timid, recent developments, the fact remains that there is no real application of SDH on analogue, digital or satellite TV that is free of charge in Turkey, which raises serious ethical issues about the role of the government in the provision of access services

\section{Conclusion}

In today's society, access to information is not only essential to conduct our lives, but it is also crucial for understanding the social environment in which we live. Symptomatic these days are the increasingly audiovisual nature of communication exchanges and the breakneck pace at which information is being created, distributed, and consumed thanks to technological advances (Díaz Cintas, 2015). In such a landscape, those unable to access audiovisual materials without the appropriate provision of customised services risk lagging behind and feeling excluded from society. And it is here that access services come into the equation as their raison d'être is to address potential disadvantages among the various segments of the population by ensuring that special measures are taken to safeguard everyone's right to enjoy the same audiovisual programmes.

With a long tradition in many countries, SDH is one of the easiest, cheapest and most convenient ways of providing access to audiovisual media for people with hearing disabilities, with the added benefits of not only having the potential to help increase the low rates of literacy 
This is the Accepted Manuscript of the article:

Gürkan, Ali and Jorge Díaz Cintas. 2018. "Developing Subtitling for the Deaf and the Hard-of-Hearing in Turkey", in Jorge Díaz Cintas and Kristijan Nicolić (eds) Fast-Forwarding with Audiovisual Translation. Bristol: Multilingual Matters, 173-191.

www.multilingual-matters.com/display.asp?k=9781783099368

levels among hearing impaired people but also to be of benefit for migrant communities residing in Turkey. Although the number of hearing impaired people in Turkey varies greatly depending on the sources consulted, the fact remains that they are a substantial number of people, for whom access services are instrumental in order to foster their social integration. Whether due to ignorance, financial objections or lack of enthusiasm, the reality is that only a handful of productions are currently being provided with SLI on free-of-charge Turkish TV platforms, while SDH and AD are still to be introduced.

On the private level, a few channels broadcast some of their foreign programmes with interlingual subtitles but these are aimed at hearing audiences and are of little use to the deaf and the hard-of-hearing collective. Even so, the paradox here lies in the fact that this segment of the audience has access, albeit partial, to these foreign productions with subtitles whereas they are totally excluded from the enjoyment of any domestic programmes, as they do not make use of any assistive services. As Turkey is a dubbing country par excellence, the situation is further compounded for the hearing impaired.

The advent of digitisation and the spread of the internet seem to be having a more positive impact on the accessibility front, with the public broadcaster, TRT, and three private ones, i.e. Show TV, Star TV and Channel D, providing some of their programmes on the internet with SDH, SLI and AD. This change of attitude seems to be instigated by the private corporations rather than the public one, not only in the number of channels leading the way, but also in the volume of programmes distributed with access services: TRT offers 33 whereas Channel D goes up to 55 programmes, all of them fully accessible.

Given that TV is arguably the most common and far reaching means of mass communication in Turkey, this sorry state of affairs emphasises the little interest that the powers that be seem to have in guaranteeing that all citizens have the same opportunities to access audiovisual materials. The recently amended directive issued by RTÜK in 2014, which obliges public and private broadcasters to provide a certain amount of SDH on news, movies and TV series, may well prove a watershed moment in the inception and promotion of accessible TV in the country. These developments are most welcome and have the potential of yielding positive results in the short or medium term but the challenges ahead are still numerous. As this piece of legislation preoccupies itself with SDH only, other audiences (i.e. the blind and the partially sighted) and access services (i.e. SLI and AD) risk being marginalised. In addition, its powers of persuasion are rather limited as it does not contemplate any punitive actions against those broadcasters not complying with the prescribed requirements, and the programmes to be covered are too narrow in terms of content (only news, films and TV series) and nature (only preprepared subtitles for recorded programmes). Indeed, to date, no SDH has been provided for live programmes on Turkish TV or the internet, making live subtitling and respeaking two very promising areas for further development and research.

As has happened in many other countries, the introduction of access services is being staggered over a period of years and early regulations on the topic tend to require service providers to subtitle only a given percentage of productions. To satisfy the target audience, these programmes should be selected based on their viewing preferences, bearing in mind the content and the broadcasting times they prefer most. Another issue which needs careful consideration is the quality of the subtitles. Given that these are very early steps in the provision of SDH on Turkish screens, it is crucial that a code of good subtitling practice and a set of guidelines be drawn according to the audience profile and needs in order to ensure decent levels of quality. To achieve these aims, hearing impaired audiences, deaf associations, universities and service providers should collaborate closely in the drafting of such guidelines, and the 
This is the Accepted Manuscript of the article:

Gürkan, Ali and Jorge Díaz Cintas. 2018. "Developing Subtitling for the Deaf and the Hard-of-Hearing in Turkey", in Jorge Díaz Cintas and Kristijan Nicolić (eds) Fast-Forwarding with Audiovisual Translation. Bristol: Multilingual Matters, 173-191.

www.multilingual-matters.com/display.asp?k=9781783099368

experience of more seasoned countries that have gone through similar processes in the past the UK, US and Spain to name a few - should be borne in mind so that lessons can be learnt from their mistakes and successes. With accessibility to the audiovisual media being in its tender infancy in Turkey, the outlook for future development is indeed very promising.

\section{References}

Akalın, Ş.H. (2013) Türk işaret dili [Turkish Sign Language]. Yeni Türkiye 55, 1496-502.

Aykan, Y. (2012) Hangi mecra [Which media]. Inn Türkiyeyi Anlama Kılavuzu-2012. Ipsos KMG, 60-6. See www.turkiyeyianlamakilavuzu.com/Turkiyeyi_Anlama_Kilavuzu_EKitap .pdf (accessed 27 January 2017)

Bolat, H., Bebitoglu, F.G., Özbas, S., Altunsu, A.T. and Köse, M.R. (2009) National newborn hearing screening program in Turkey: struggles and implementations between 2004 and 2008. International Journal of Pediatric Otorhinolaryngology 73 (12), 1621-1623.

Caimi, A. (2013) Subtitles and language learning'. In Y. Gambier and L. van Doorslaer (eds) Handbook of Translation Studies, 4 (pp. 167-175). Amsterdam: John Benjamins.

Çağlar, S. (2012) Right of accessibility for persons with disabilities and accessibility in Turkey'. Ankara Üniversitesi Hukuk Fakültesi Dergisi 61 (2), 541-598.

Castells, M. (2010) The Rise of the Network Society: The Information Age: Economy, Society and Culture (Vol I; $2^{\text {nd }}$ edn, with a new preface). Oxford: Blackwell.

Crawford, S. (1983) The origin and development of a concept: the information society. Bulletin of the Medical Library Association 71 (4), 380-385.

Díaz Cintas, J. (2015) Technological strides in subtitling'. In S-W. Chan (ed.) Routledge Encyclopedia of Translation Technotogy (pp. 632-643). London: Routledge.

Dutton, W.H. (2004) Social Transformation in an Information Society: Rethinking Access to You and the World. UNESCO. See http://unesdoc.unesco.org/images/0015/001520/ 152004e.pdf (accessed 27 January 2017).

Ellcessor, E. (2012) Captions on, off, on TV, online accessibility and search engine optimization in online closed captioning. Television \& New Media 13 (4), 329-352.

Girgin, C. (2006) History of higher education provision for the deaf in Turkey and current applications at the Anadolu University. The Turkish Online Journal of Educational Technology 5 (3), 6-11.

Gök, S. (1958) Dünyada ve Türkiye'de sağır dilsiz okulları tarihçesi ve eğitim sistemi [History and Education System of Deaf and Mute Schools in the World and in Turkey]. İstanbul: Hüsnü Tabiat Press.

Gündüz, M. (2014) Osmanlı'dan Cumhuriyet'e engelli eğitimi üzerine gelişmeler" [From Ottoman to Republic, developments on the education of disabled people]. Eğitime Bakış 31, $5-14$.

Holvast, J., Duquenoy, P. and Whitehouse D. (2005) The information society and its consequences: lessons from the past' In J. Berleur and C. Avgerou (eds) Perspectives and Policies on ICT in Society (pp. 135-152). New York: Springer.

ILNET (n.d.) About ILNET. Independent Living Network. See http://ilnet.enil.eu/aboutilnet/ilnet (accessed 27 January 2017).

International Telecommunications Union (2015) ICT Facts and Figures. The World in 2015. Geneva. See www.itu.int/en/ITU-D/Statistics/Documents/facts/ICTFactsFigures2015.pdf (accessed 27 January 2017). 
This is the Accepted Manuscript of the article:

Gürkan, Ali and Jorge Díaz Cintas. 2018. "Developing Subtitling for the Deaf and the Hard-of-Hearing in Turkey", in Jorge Díaz Cintas and Kristijan Nicolić (eds) Fast-Forwarding with Audiovisual Translation. Bristol: Multilingual Matters, 173-191.

www.multilingual-matters.com/display.asp?k=9781783099368

Karahasan, F. (2012) Ülkemizdeki dijital uçurum kapanmıyor [Digital divide in our country is not decreasing]. In Türkiyeyi Anlama Kllavuzu - 2012. Ipsos KMG, 75-82. See www. turkiyeyianlamakilavuzu.com/Turkiyeyi_Anlama_Kilavuzu_EKitap.pdf (accessed 27 January 2017).

Kemaloğlu, Y.K. (2010) Ülkemizde Isşitme Engellilerin (IYYE ve FITYY) Nüfüsu Ne Kadardır? [What Is the Population of Hearing Impaired People (deaf and Deaf) in Our Country]. Ankara: Gazi University. See http://engelsiz.karatekin.edu.tr/e_isit/dosya/EK-01.pdf (accessed 27 January 2017).

Kemaloğlu, Y.K. (2014) Disability, otorhinolaryngologic practice and sign langauge. Bozok Tip Dergisi 1 (1), 38-53.

Kemaloğlu, Y.K. and Kemaloğlu, P.Y. (2012) The history of sign language and deaf education in Turkey. Kulak Burun Boğaz İhtisas Dergisi 22 (2), 65-76.

Kothari, B. and Tathagata, B. (2007) Same Language Subtitling on TV: Impact on Basic Reading Development among Children and Adults. Ahmedabad: Indian Institute of Management. See www.globalgiving.co.uk/pfil/593/SLS_Impact_Study_2007.pdf (accessed 27 January 2017).

Kothari, B., Pandey, A. and Chudgar, A.R. (2004) Reading out of the idiot box: Same-language subtitling on television in India. Information Technologies and International Development 2 (1), 23-44.

Linebarger, D., Taylor Piotrowski, J. and Greenwood, C.R. (2010) On-screen print: The role of captions as a supplemental literacy tool. Journal of Research in Reading 33, 148-167.

Miles, M. (2009) Deaf People, Sign Language and Communication, in Ottoman and Modern Turkey: Observations and Excerpts from 1300 to 2009. From Sources in English, French, German, Greek, Italian, Latin and Turkish, with Introduction and Some Annotation. Farsta: Independent Living Institute. See www. independentliving.org/miles200907.html (accessed 27 January 2017).

Mliczak, R. (2015) Signing and subtitling on Polish television: A case of (in)accessibility. In R. Baños-Piñero and J Díaz-Cintas (eds) Audiovisual Translation in a Global Context: Mapping an Ever-changing Landscape (pp. 203-224). Basingstoke: Palgrave Macmillan.

Neves, J. (2005) Audiovisual Translation: Subtitling for the Deaf and Hard of Hearing. PhD thesis, Roehampton University, London. See http://roehampton.openrepository.com/ roehampton/handle/10142/12580 (accessed 27 January 2017).

RTÜK (2007) Özürlülerin Televizyon İzleme/Dinleme Eğilimleri Araştırması [Research on the Television Watching/Listening Trends of the Disabled People]. Radyo ve Televizyon Üst Kurulu. See www.rtuk.org.tr/sayfalar/IcerikGoster.aspx?icerik_id=baae3e07-7c34-40cba48a-1adc8b77fe2e (accessed 27 January 2017).

RTÜK (2013) Televizyon İzleme Eğilimleri Araştırmast-2012 [Research on Television Viewing Trends]. Radyo ve Televizyon Üst Kurulu. www.rtuk.org.tr/sayfalar/IcerikGoster.aspx? icerik_id=974d7f37-c7e0-4335-a47e-0f9757c306a1 (accessed 27 January 2017).

Soysal, Y. (2001) Hitit din ve sosyal hayatında LU/MUNUSU. HU B 'sağır' [The 'deaf' LU/MUNUSU. HU B in the religious and social life of Hittites]. Akten des IV. Internationalen Kongress für Hethitologie. Würzburg, 4-8 October 1999 (pp. 652-699). Wiesbaden: Harrassowitz Verlag.

State Planning Organization (2006) Information Society Strategy. See http://unpan1.un.org/ intradoc/groups/public/documents/unpan/unpan025636.pdf (accessed 27 January 2017). 
This is the Accepted Manuscript of the article:

Gürkan, Ali and Jorge Díaz Cintas. 2018. "Developing Subtitling for the Deaf and the Hard-of-Hearing in Turkey", in Jorge Díaz Cintas and Kristijan Nicolić (eds) Fast-Forwarding with Audiovisual Translation. Bristol: Multilingual Matters, 173-191.

www.multilingual-matters.com/display.asp?k=9781783099368

State Planning Organization (2011) Information Society. Statistics of Turkey 2011. See www.bilgitoplumu.gov.tr/Documents/1/Yayinlar/Turkish_Information_Society_Statistics_ 2011.pdf (accessed 27 January 2017).

Stewart, M.A. and Pertusa, I. (2004) Gains to language learners from viewing target language closed-captioned films. Foreign Language Annals 37, 438-442.

Story, M.F., Mueller, J.L. and Mace, R.L. (1998) The Universal Design File: Designing for People of All Ages and Abilities. Raleigh: NC State University, the Centre for Universal Design. See www.ncsu.edu/ncsu/design/cud/pubs_p/pudfiletoc.htm (accessed 27 January 2017).

TÜIK (2010) Survey on Problems and Expectations of Disabled People. Türkiye İstatistik Kurumu [Turkish Statistical Institute]. See www.turkstat.gov.tr/IcerikGetir.do\%3Fistab_id \%3D244 (accessed 27 January 2017).

TÜIK (2011) Population and Housing Census. Türkiye İstatistik Kurumu [Turkish Statistical Institute]. See http://eyh.aile.gov.tr/data/5485bba0369dc5596417ba49/nka_2011_engellilik .pdf (accessed 27 January 2017).

Turgut, K. and Taşçı, S.A. (2011) Historical perspective on first deaf schools, education methods and deafness in Turkey. In Conference of International Sign Language Users. Ankara: Gazi University.

Web 1: www.un.org/disabilities/convention/conventionfull.shtml (accessed 27 January 2017).

Web 2: www.tuik.gov.tr/PreTablo.do?alt_id=1017 (accessed 27 January 2017).

Web 3: http://eyh.aile.gov.tr/data/55100f25369dc5c9d8afa5fc/Sempozyum_Kitap_TR.pdf (accessed 27 January 2017).

Web 4: www.resmigazete.gov.tr/main.aspx?home=http://www.resmigazete.gov.tr/eskiler /2014/04/20140403.htm\&main=http://www.resmigazete.gov.tr/eskiler/2014/04/20140403. htm (accessed 27 January 2017).

World Health Organisation (2013) Millions of People in the World Have Hearing Loss that Can Be Treated or Prevented. See www.who.int/pbd/deafness/news/ Millionslivewithhearingloss.pdf (accessed 27 January 2017).

Yüksel, D. and Tanrıverdi, B. (2009) Effects of watching captioned movie clip on vocabulary development of EFL learners. Turkish Online Journal of Educational Technology 8 (2), 4854.

Zárate, S. (2014) Subtitling for Deaf Children: Granting Accessibility to Audiovisual Programmes in an Educational Way, PhD thesis, UCL London. 